\title{
REASONS TO CONSIDER CÉLESTIN FREINET'S PEDAGOGY STILL CURRENT
}

Ivan FORTUNATO ${ }^{1}$

2016 was a year marked by the 50th anniversary of the death of Célestin Freinet. Since he left, school education has changed very little, and it is possible to infer that the past is still present (FORTUNATO, 2016a). Almost 100 years ago, this educator had already found that school practices do not make sense to the lives of learners, as well as the rigidity of its syllabus and repetitive activities, focusing on memorization, do not fit into the lives of learners. Such assertions are still valid. In fact, I dare to state that in the last 50 years the school seems to have regressed, for in the absence of one of the great heroes of education, it became easy to resign the transformative work, returning to the inertial secular traditionalism (FORTUNATO, 2016b). These findings lead, in principle, to a list of regrets.

Therefore, I regret not having met Freinet in my life, but only through his hopeful writings. I regret that I did not study at an institution participating in his Modern School Movement. I regret, as a teacher, giving in to bureaucratic pressures and the generalizing system of evaluating, approving and reproving students, controlling attendance, and demanding insignificant tasks.

On the other hand, in making contact with the life and work of Célestin Freinet, especially his militancy in the school of basic education, the "battles" he won, his struggle and his techniques (see LEGRAND, 2010), it became possible to see brighter and more fertile path to education. Thus, far from complaining about his absence in my school life, it is preferable to list what I have learned with this educator. Actually, I would venture to note that if it had not been for this approach with Freinet's pedagogy, I would probably have abandoned my teaching career or, worse, I would have yielded to the indifference and inertia of secular school education, namely: teaching/instructing/indoctrinating students, just as it has always been done.

${ }^{1}$ Doutor em Geografia pela UNESP. Professor do Programa de Pós-Graduação em Ciências Humanas e Sociais-UFABC, do Programa de Pós-Graduação em Educação-UFSCar-Sorocaba e do IFSPItapetininga. Email: ivanfrt@yahoo.com.br. 
In this sense, I am proud to have found, at random, a book written by Freinet (1975) in which I found the support to continue teaching. His techniques motivated me to work for a freer education and to seek new ways of educating (FORTUNATO, 2013). Thus, I am proud that today I am able to conduct activities according to the interests of each student - minimum that is - allowing each one to take some particular advantage from the compulsory classes. I am also proud to struggle, day after day, to teach without the curricular halter and the rigidity of tight schedules. In addition, I understood from Freinet that life happens outside school walls. So that made me take students enrolled in my classes into schools and educational institutions. The purpose of this is that we can, through direct experience with young people and children, to learn and to teach cooperatively.

Thus, while I was developing and seeking to mature these pedagogical ideas, I went over the works written by Freinet, finding support in those he himself wrote down as references, especially Dewey and Decroly. But, as Elise Freinet (1979) noted, her husband has surpassed the renowned thinkers, precisely because he did not change the challenges of being in school and teaching children to recognize themselves, recognize their peers and the world that surround them, for the safety of university walls. This is because Freinet understood that education could only be transformative if it is developed in practice, in the direct contact with those who have the right (and the desire) to learn.

I discovered, then, that his pedagogical proposal still lives throughout the world in the various Freinet Networks and in the Modern School Movements. This means that around the planet, collectives of educators get together to recover his teachings and demonstrate that his assumptions are still valid, and are present (or necessary) in the daily school life. In Brazil, for example, we have the Network of Educators and Researchers of Freinet Education (the REPEF), promoting annual meetings to share practices and pedagogical knowledge. That is why it is possible - and necessary - to talk about the timeliness of Freinet pedagogy.

This idea is not new, since it was presented by Imbernon (2010) when he published the book "Las invariantes pedagógicas y la pedagogia Freinet cincuenta años después". In it, the author recovered memories of how he met Freinet (from his writings), and how he was influenced by him to think of more practical ways of teaching, and of the importance of practicing the teaching profession in a progressive way. I see myself in this book, because, just like Imbernon (2010), I believe that 
Célestin Freinet's pedagogy is one of the most important for the school; I also take it as a current practice and, likewise, I became aware of his techniques and theories in a "underground" way, that is, outside the university curriculum that assumed the ideal for teacher education.

There are other coincidences: we both recognize the validity and permanence of Freinet's "pedagogical invariants", which are solid statements about education that are valid in any context. For example, Freinet realized that the nature of the child does not differ from the nature of the adult, that is, they are human beings who learn in a very similar way. Other invariants are related to teaching techniques and the need to overcome the old school: no one - be it a child or an adult - likes imposed and meaningless tasks, but everyone takes pleasure in performing activities that they consider important for their own lives (FORTUNATO; CUNHA, TEMPLE, 2016). These pedagogical invariants can be understood as Freinet's last effort for school education, since he wrote them almost at the end of his life. The invariants, along with what he called "a practical guide" to work in the school, were published in his last book, this being a posthumous work (FREINET, 1969).

Another similarity in Imbernon's relationship with Freinet to my own relationship with Freinet is that we both feel somewhat indebted to the French educator. Even if his influence on my practice and pedagogical beliefs is quite often expressed, it seems that I am far from matching his legacy. Thus, like Imbernon, I have also looked for ways to emphasize his singular importance for the school.

With that in mind, it was trying to minimize this debt with Freinet that I decided promoted this "meeting" between teachers and researchers who see in his pedagogy a very current and lively way of educating. The texts collected in this dossier were produced in Brazil, Spain, Portugal and Canada with the purpose of recalling Freinet's struggle for school education. They also express a singular way to both thank his lessons and to spread his words that inspire to aim for nothing but a less frustrating teaching, and a more rewarding learning.

\section{Referências}

FREINET, C. As técnicas de Freinet da Escola Moderna. 4ª ed. Lisboa, Portugal: Editorial Estampa, 1975. 
FREINET, C. Pour l'école du peuple. Paris: Maspero, 1969.

FREINET, É. O itinerário de Célestin Freinet: a livre expressão na pedagogia Freinet. Rio de Janeiro, Brasil, Livraria Francisco Alves Editora S.A., 1979.

FORTUNATO, I. Aprendendo com Célestin Freinet: o passado ainda é presente. Tendência Pedagógicas, Madrid, v. 27, n. 1, p. 251-258, $2016 \mathrm{a}$.

FORTUNATO, I. 50 Anos sem Célestin Freinet, 500 Anos de Retrocesso das Práticas Escolares. Journal for Educators, Teachers and Trainers, Granada, v. 7, p. 174-181, $2016 b$.

FORTUNATO, I.; CUNHA, C. R.; TEMPLE, C. Célestin Freinet's pedagogical invariants: a pathway to free and collaborative school education. Quaderni di didattica della scrittura, Barletta, v. 26, p. 44-51, 2016.

FORTUNATO, I. Algumas ideias de Celestin Freinet para motivar a docência. Direcional Educador (Impresso), São Paulo, v. 105, p. 34-36, 2013.

IMBERNON, F. Las invariantes pedagógicas y la pedagogia Freinet cincuenta años después. Barcelona: Graó, 2010.

LEGRAND, Louis. Célestin Freinet. Trad. José Gabriel Perissé. Recife, Fundação Joaquim Nabuco, Editora Massangana, 2010.

\section{Como referenciar este artigo}

FORTUNATO, Ivan. 50 Célestin Freinet - Atual / Actual / Present. Revista IberoAmericana de Estudos em Educação, Araraquara, v. 12, n. esp. 1, p.550-553, 2017. Disponível em: <http://dx.doi.org/10.21723/riaee.v12.n.esp.1.2017.9660>. E-ISSN: 1982-5587. 